\title{
Thermal Energy Storage at a Federal Facility
}

The Dallas Veterans Administration Medical Center and Texas Utilities Electric Company join in an unprecedented partnership to lower energy costs.

\section{Overview}

The Dallas, Texas Veterans Administration (VA) Medical Center was the first VA medical facility in the nation to use thermal energy storage technology to reduce operating costs. A partnership with Texas Utilities Electric Company (TU Electric ) made implementing this technology possible. The Medical Center now shifts a significant portion of its energy demand away from the peak cost period to a lower cost period. Supporting this technology benefits the utility because it relieves pressure to construct new, increasingly more costly power plants. Shifting a large energy demand away from the peak period enables the utility to maximize its generating plants. Thus it saves money for both the customer and the utility.

\section{Background}

Like most large commercial utility customers, the VA Medical Center's annual electrical costs were based on a rate that is 80 percent of the highest demand charged during the year. If the facility could find a way to lower the demand, it could reduce its overall annual expense for electrical service.

The system selected was a stratified chilled water storage tank. The tank provided 24,628 ton-hours of thermal storage. In the summer of 1997 thermal storage reduced peak demand by $2,934 \mathrm{~kW}$, cutting annual electricity costs by $\$ 223,650$. Installing the system also allowed the utility to reduce its costs by getting more use out of its existing generating plants. The need to build new capacity lessened considerably.

\section{Project Summary}

On February 6, 1996, the VA Medical Center contracted with TU Electric for financial support of the project. It was agreed that TU Electric would build the tank, finance the cost, and let the Medical Center pay for the thermal storage on its electric bill. The utilities provided $\$ 500,000$ of the total cost of $\$ 2.2$ million required for design and installation. Savings resulting from installation of the thermal storage technology will allow the VA to recoup its investment within 7 years.
Initially, a feasibility study was conducted on how to add thermal storage to the existing central plant. This study offered six alternate solutions, each with estimated construction costs, maintenance costs, utility savings, and lifecycle cost analysis. The partners selected a stratified water thermal storage system with a 3.3-million-gallon tank at its core, which has 3,000 tons of chiller capacity for 8 hours. (The tank is considerably larger than an Olympic-size swimming pool.) The system became operational in the fall of 1996.

The storage tank is filled with chilled water every night. Then every day, from noon until 8:00 p.m., the hospital draws its chilled water from the tank to meet its cooling load, instead of requiring continuous electric service to operate on-site chillers.

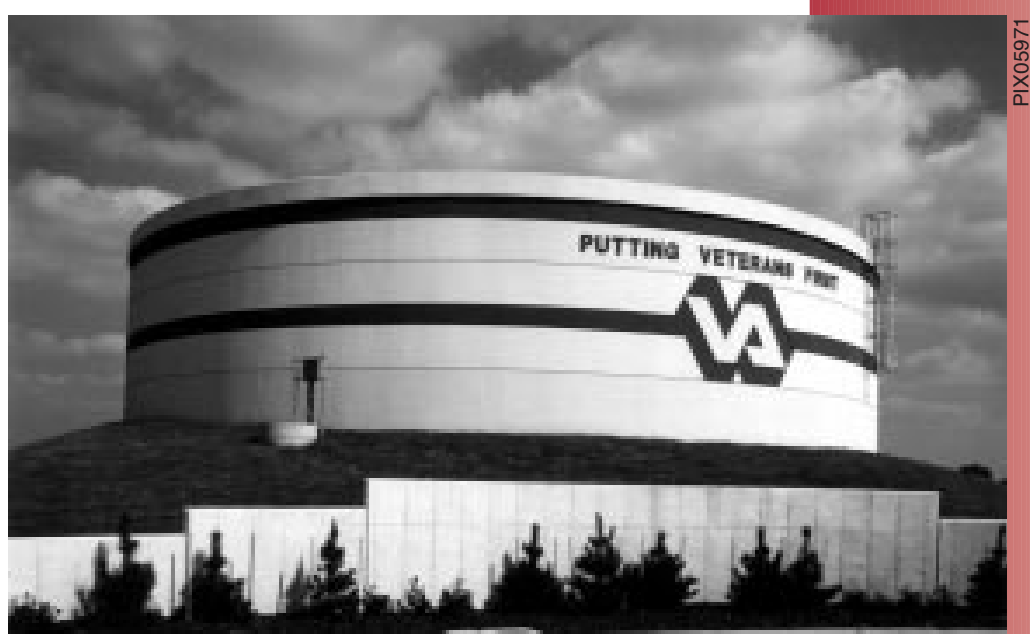

The VA Medical Center relies on this stratified water thermal storage system, with a 3.3-million-gallon-tank, to balance energy demands during peak needs.

As an added feature, the thermal storage system also doubles the capacity of the hospital's central plant. If the hospital expands, the VA could use the thermal storage system and its existing cooling system at the same time, avoiding additional capital investment.

\section{Benefits of Utility Contracting}

Although TU Electric was involved in about 200 thermal storage systems before this project, this was its first project at a VA facility. It was also TU

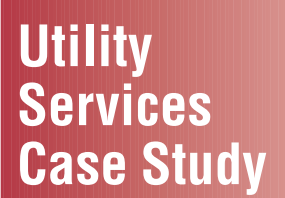

Utility Case Study 
Electric's first partnership arrangement in which the utility agreed to design, build, and help find thirdparty financing for a thermal storage system. The authority for this partnership was existing Federal legislation that allows government to enter into sole-source arrangements with utility companies for services generally available to other customers.

\section{Lessons Learned}

\section{Participant Education}

The Department of Energy's Federal Energy

Management Program (FEMP) worked closely with both parties to help make this project happen. The knowledgeable FEMP liaison staff member provided necessary training and support, which put this project on track.

\section{Quality Subcontractor Selection}

Another lesson learned was in the utility's foresight to serve only as the project's prime contractor. TU Electric retained one of the nation's leading architectural and engineering firms, Carter \& Burgess, Inc., of Ft. Worth, Texas, to provide design, architecture, and construction management services. The utility was committed to the project's success and used the best resources in the most cost-effective manner.

\section{Looking Ahead}

Successful completion of this pilot project with a Federal agency will help TU Electric establish other successful Federal customer partnerships. It also serves as a testimonial for integrating this technology at other Federal sites.

\section{For More Information}

FEMP Help Desk:

(800) DOE-EREC (363-3732)

Fax: (202) 586-3000

Internet: http://www.eren.doe.gov/femp

Brad Gustafson

Utility Services Program Manager

DOE FEMP

(202) 586-2204

Bill Sandusky

Program Manager Energy Division

Pacific Northwest National Laboratory

(509) 375-3709

For more information about the project, contact:

Randy Goode

Federal Market Manager

Texas Utilities Electric Company (214) 812-2713

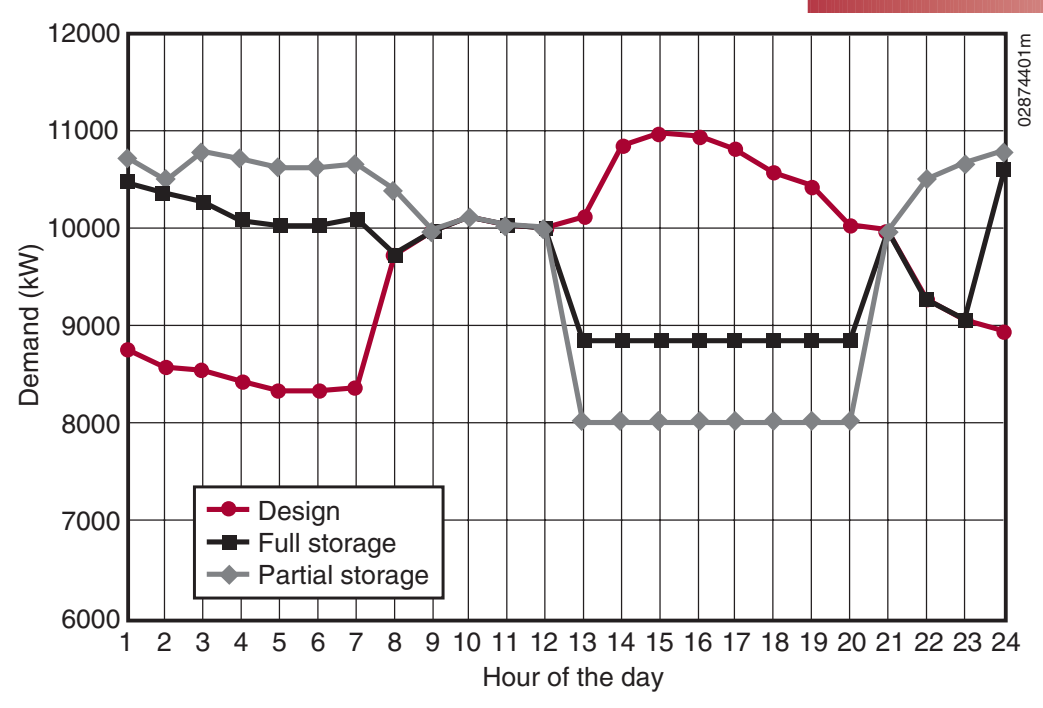

This graph represents daily demand in August for both current design conditions and the partial and full thermal storage conditions. The hospital can meet cooling requirements by producing chilled water during the period of lowest electric cost, then storing it for use during periods of high electric cost.

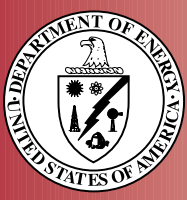

Produced for the

U.S. Department

of Energy by the

National Renewable

Energy Laboratory,

a DOE national

laboratory 